\title{
Integration of Burning with Mechanical Manipulation of South Texas Grassland ${ }^{1}$
}

\section{J. D. DODD AND S. T. HOLTZ ${ }^{2}$}

Professor and Graduate Research Assistant, Department of Range Science, Texas AઐM University, College Station.

\section{Highlight}

Roller chopping and shredding of woody plants reduced the overall stature, canopy cover, and woody plant density, but stem density increased due to basal sprouting. Two consecutive years of late summer burns following mechanical treatments did not significantly lower woody plant or stem densities. Mechanicalherbicide stump treatment following mechanical treatment, but prior to burning did not affect woody plant or stem densities or the stem:plant ratio. Mechanical clearing in combination with fire promoted secondary plant succession. Treatment combinations resulted in highest total herbage production, grass production, and herbaceous basal cover. Burning reduced litter cover, while roller chopping and shredding had little effect.

The Texas ranching industry depends primarily on herbage produced by native grasslands. Woody plants have invaded and reduced available forage on $82 \%$ of the 107 million acres of Texas rangeland over the past half century (Leinweber, 1965). About 13 of the 17 million acres of the Rio Grande Plain Resource Area of Texas supports at least a $20 \%$ brush canopy cover (U. S. Dep. Agr., 1964). Generally, mechanical and chemicalcontrol methods have not proven satisfactory for mixed brush stands in the resource area.

Many aspects of the total grass-

\footnotetext{
${ }^{1}$ Technical bulletin No. TA-9193 Texas Agricultural Experiment Station, College Station, Texas. Received May 14, 1971.

${ }^{2}$ This research was possible only with the cooperation of Mr. Holman Cartwright, owner and Mr. Clarence Myers, Manager, of the Clair Cartwright Estate Ranch.
}

land habitat have changed during the last 75 to 100 years (Humphrey, 1953). Grassland vegetation evolved through an intimate ecological relationship with fire (Humphrey, 1958). When the desert grasslands were grazed only by game animals, much of the annual forage production was not utilized and served as a fuel source for natural fires. These natural fires produced temperatures hot enough to kill most woody plants. Such a fuel source does not occur on most grasslands today. Humphrey (1953) stated that size of woody plants in grasslands today reduces effective control by fire. Young, woody plants are highly susceptible to fire and few seedlings survive. Restriction of the potential seed source must be important in maintaining prairies free of woody plants.

Britton and Wright (1971) correlated weather and fuel variables with mesquite (Prosopis glandulosa var. glandulosa Torr.) damage by fire in the Southern Mixed Prairie of Texas. Relative humidity and wind speed were important variables for predicting tree-stem ignition. Fine fuel moisture content and total fuel also were important variables. Mesquite mortality increased as grass fuel increased.

Burning may directly affect certain attributes of desirable plants in a grassland ecosystem. Late winter burns increased protein and phosphorus content of new grass growth on pine-bluestem ranges in Louisiana (Campbell and Cassody, 1951). Prescribed burning in the Flint Hills of Kansas stimulated early spring growth of grasses, uniform grazing with rough removal, increased plant cover, and increased forage production in Kansas (Hensel, 1923; Anderson, 1964). However, Aldous (1934) reported reduced forage production, particularly from early-spring burns, in the same region. Burned bluestem (Andropogon spp.) clones were more leafy than unburned clones early in the growing season.

Fire also affects undesirable herbaceous species. Owensby and Anderson (1967) reported reduced weed densities from late-spring burns in Kansas. However, weed yields in early- and mid-spring burned pastures were not significantly reduced. Aldous (1934) reported buckbrush (Symphoricarpos sp.) control in Kansas with prescribed burns in May. Prescribed burns in California reduced the number of viable seeds produced by medusahead (Elymus caputmedusae L.) (McKell et al., 1962). 
Box et al. (1967) reported the effects of various mechanical treatments in combination with fall prescribed burns on woody plant frequency and forage production in South Texas chaparral communities. Mechanical control techniques for woody plants have been evaluated on the Rio Grande Plain of Texas (Dodd, 1968).

Mixtures of 4-amino-3,5,6-trichloropicolinic acid (picloram), an experimental herbicide, and 2,4,5trichlorophenoxy acetic acid (2,4, 5-T) controlled huisache (Acacia farnesiana (L.) Willd.) and 2,4,5-T alone controlled mesquite (Bovey et al., 1970). Aerial applications of picloram and mixtures of picloram and 2,4,5-T also controlled blackbrush (Acacia rigidula Benth.) and several other woody species, but were ineffective on Texas (Mexican) persimmon (Diospyros texana Scheele), wolfberry (Lycium berlandieri Dunal), and agarito (Berberis trifoliolata Moric.).

The purpose of this study was to determine the effects of roller chopping and shredding, shreddinghcrbicide stump treatment and prescribed burns on density of woody species and the basal cover, species composition and production of herbaceous vegetation.

\section{Area and Methods}

The study was conducted in Goliad County, Texas. This area is similar to the Rio Grande Plain Resource Area (Gould, 1969). However, traces of the Post Oak Savannah and the Gulf Coast Prairie vegetations intergrade throughout the region.

Long-term records indicate an average yearly rainfall of about 30 inches. $^{3}$ Range of recorded annual rainfall includes a low of 9.4 inches in 1917 and a high of 48.8 inches in 1919. Peak periods of rainfall normally occur from April to June and August to October.

High summer temperatures and an average frost free period of 288

${ }^{3}$ Meteorological records, Texas A\&M University Agricultural Research Station at Beeville, Texas.

Table 1. Treatment sequence and combinations applied to mixed-brush stands in Goliad County, Texas.

\begin{tabular}{ccccc}
\hline & \multicolumn{3}{c}{ Treatments } \\
\cline { 2 - 5 } Area & $\begin{array}{c}\text { Roller } \\
\text { chopped } \\
(\mathrm{RC})\end{array}$ & $\begin{array}{c}\text { Shredded } \\
(\text { S })\end{array}$ & $\begin{array}{c}\text { “Chem-Cut” } \\
(\mathbf{C C})\end{array}$ & $\begin{array}{c}\text { Burned } \\
(\mathbf{B})\end{array}$ \\
\hline A & 1965 & $1966 \& 1967$ & - & $1966 \& 1967$ \\
B & 1965 & 1967 & -1966 & $1966 \& 1967$ \\
C & 1967 & 1967 & - & - \\
D & & - & - &
\end{tabular}

days characterize the area. Continuous warm temperatures may contribute to evaporation usually exceeding precipitation every month of the year. Periodic cold temperatures and subfreezing weather, usually of short duration, characterize the short winters. Two seasons with moisture and temperature satisfactory for rapid plant growth, April through June and September through October, usually occur each year.

A loam range site covers approximately $90 \%$ of the study area. The remainder is a shallow range sitc (U. S. Dep. Agr., 1965). Major soils of the loam site are fine sandy loams of the Goliad, Miguel, and Delfina series. These soils are deep, gray, or light brown fine sandy loams, usually over caliche or limestone. Subsoils are relatively heavy sandy clay loams. Water intake is moderate and water storage capacity is high. Roots penetrate these soils with little difficulty. The loam site has few permanent production limitations and is only moderately susceptible to erosion.

Climax vegetation for the loam range site is dominated by little bluestem (Andropogon scoparius (Michx.)) and sideoats grama (Bouteloua curtipendula (Michx.) Torr.). Other decreaser species are Indiangrass (Sorghastrum nutans (L.) Nash.), lovegrass tridens (Tridens eragrostoides Vasey \& Scribn.), green sprangletop (Leptochloa dubia (H.B.K.) Nees.), and Texas cupgrass (Eriochloa sericea (Scheele) Munro). Common woody invaders are mesquite, spiny hackberry (Celtis pallida Torr.), agarito, lotebush
(Condalia spp.), blackbrush, and Mexican persimmon. Post oak (Quercus stellata Wang. var. stellata) and live oak ( $Q$. virginiana Mill. var. virginiana) often occur. In excellent range condition this site can produce $5,500 \mathrm{lb}$./acre of air-dry herbage (U. S. Dep. Agr., 1965).

Major soils of the shallow range site are loams of the Goliad and Zapata series. These soils generally vary from 10 to 20 inches deep with very shallow outcrops throughout the site. The soils are dark gray, crumbly clay over powdery, erodable caliche and pronounced sheet erosion is often evident. A crust usually forms on the bare soil surface. Water storage is limited by soil depth. Vegetation recovery is slow and production is limited by the droughty characteristics of the site even though soil fertility is considered high.

Major decreaser species on the shallow range site are little bluestem and sideoats grama. Other decreasers in the climax are vine mesquite (Panicum obtusum H.B.K.), plains lovegrass (Eragrostis intermedia Hitchc.), and feathery bluestem (Bothriochloa spp.). Common woody invaders are spiny hackberry, lotebush, Mexican persimmon, and huisache. Kidneywood (Eysenhardtia texana Scheele), an increaser, is limited in occurrence. In excellent range condition and with favorable growing conditions this site will produce about 3,000 lb./acre air-dry herbage. Production may be as low as $1,200 \mathrm{lb}$./acre in dry years (U. S. Dep. Agr., 1965).

Four discrete areas, "A", "B", 


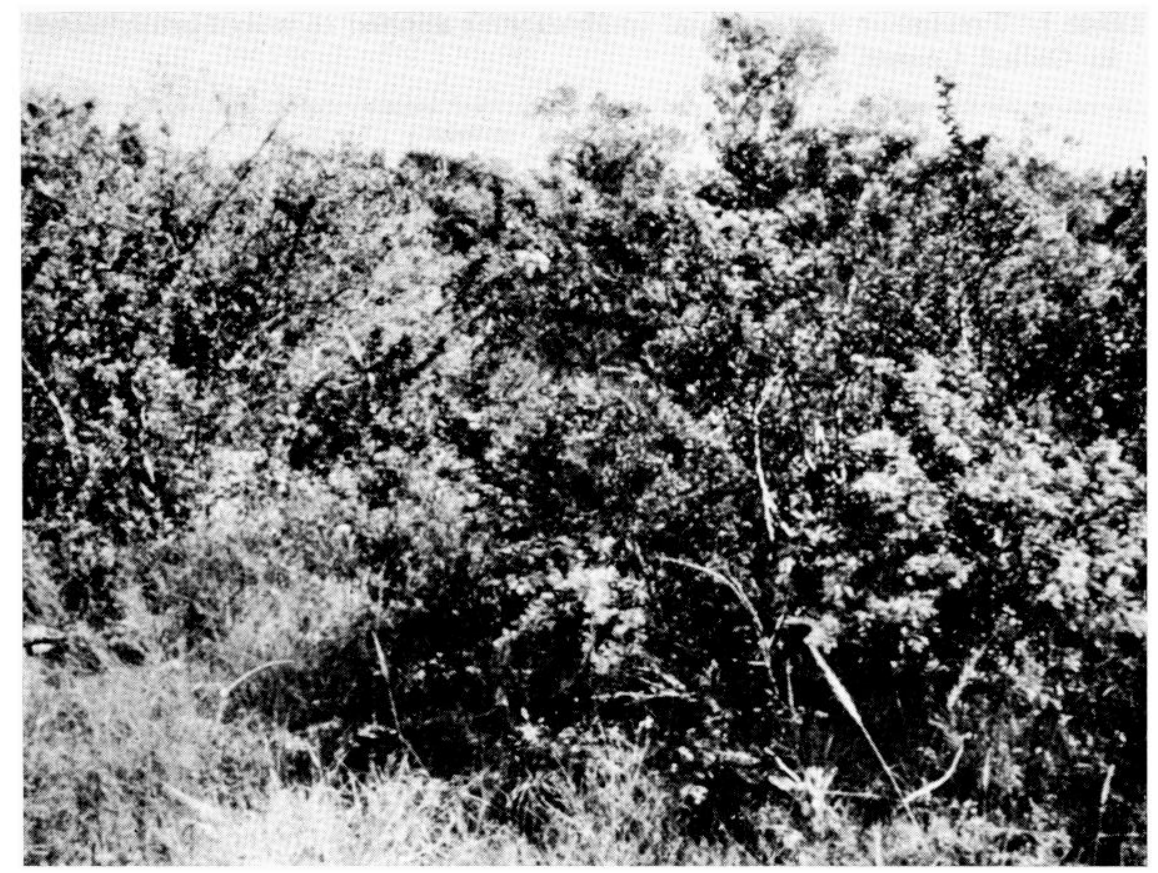

Fig. 1. Typical mixed-brush vegetation (Area D) in Goliad County, Texas. Woody species present included blackbrush, Mexican persimmon, and lotebush which were 6 to 8 feet in height.
“C', and "D", were treated (Table 1). The original vegetation (Fig. 1) on Area A was roller chopped in 1965, shredded in 1966 and in 1967. Mechanical treatments were followed by prescribed burns in $\mathrm{Au}$ gust 1966 and in August 1967 (Fig. 2). Area B was originally roller chopped in 1965, shredded with "Stull Chem-Cut"4 in 1966, shredded with conventional equipment and prescribed burned in August 1966 and August 1967. Area C was originally roller chopped in 1967 and shredded the fall of 1967. Area D was untreated and maintained as a control area. The four areas, ranging from 10 to 20 acres, were fenced the spring of 1968 to control grazing and facilitate treatment evaluation.

Species composition and basal cover of the grasses and litter cover were determined by the basal con-

4 The "Stull Chem-Cut" method is trademarked by the Stull Chemical Co., San Antonio, Texas and consists of a sprayer mounted under the shredder housing. The herbicide, $2 \mathrm{lb}$. acre 2,4,5-T amine, was immediately applied as a broadcast spray to the cut-stump surfaces. tact system (Clark et al., 1942) with a 10-point frame (Levy and Madden, 1933) at regular intervals along each of two randomly located transect lines in each treatment. The number of samples, 120, 10-point frames in each area, was governed by density and distribution of the vegetation (Whitman and Siggeirssity were recorded in 15 , permanent $1 \mathrm{~m}$ by $10 \mathrm{~cm}$ quadrats at regular intervals along two randomly located transect lines. Herbaceous vegetation production was determined by clipping $15, .5 \mathrm{~m}$ by $1 \mathrm{~m}$ quadrats at ground level in each treatment. Herbage was separated into grass and forb classes. Perennial and annual species were included in the grass class while sedges were included in the forb class. All measurements were made in June 1968, following the period of maximum spring growth.

Fifteen permanent, meter-square quadrats were used to record shortterm changes in density and composition of woody species (Oosting, 1942). The permanent quadrats were located at regular intervals along two randomly selected lines in each plot. The number of live woody plants and number of live stems per plant in each permanent quadrat were recorded by species in June 1968. son, 1954). Forb frequency and den-

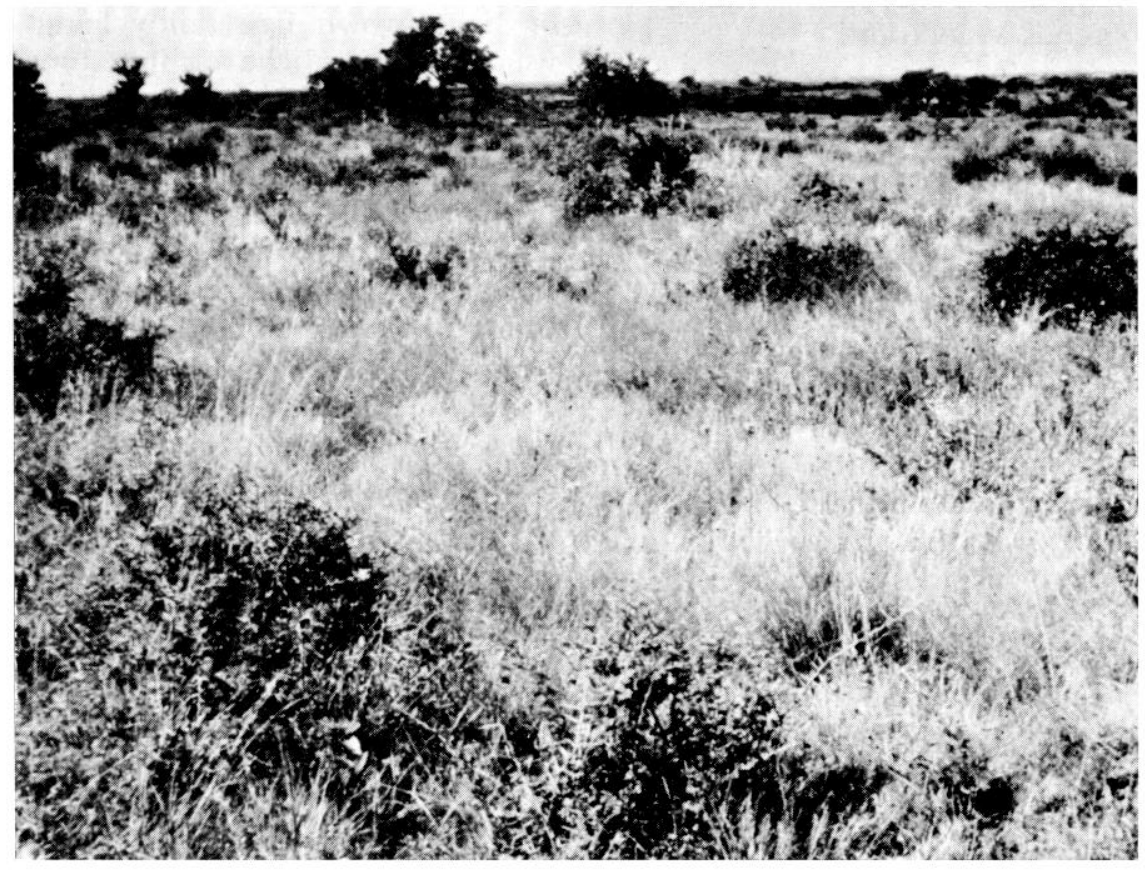

Fig. 2. Mixed brush stand (Area A) roller chopped in 1965, shredded in 1966 and 1967 and burned in August 1966 and 1967. Blackbrush plants were 2 to 3 feet tall in 1968. 


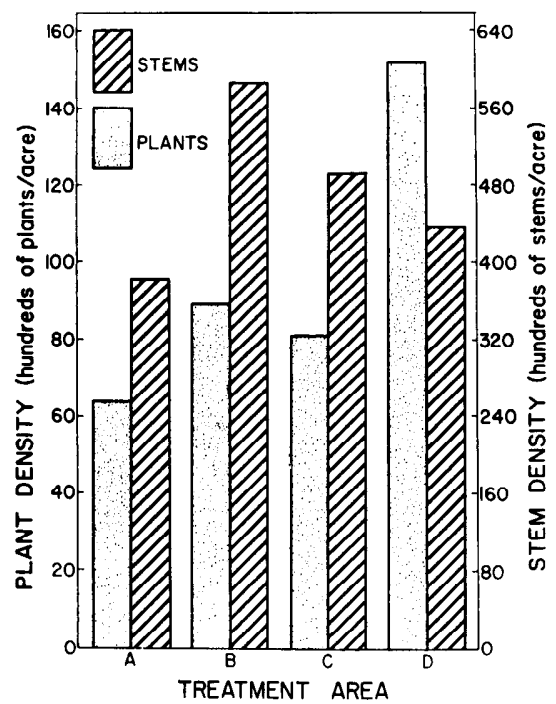

FIG. 3. Total woody plant density and stem density on four treated areas in 1968. Area A was roller chopped, shredded and burned (RC, S, B); Area B was roller chopped, "Chem-Cut," shredded, and burned (RC, CC, S, B); Area $\mathrm{C}$ was roller chopped and shredded (RC, S); Area D was untreated.

\section{Results}

Woody plant densities were reduced by all methods of vegetation manipulation (Fig. 3). Composite densities of woody plants declined 58, 41, and $47 \%$ on Areas A, B, and $\mathrm{C}$, respectively. This decline also was evident for individual species (Fig. 4). Blackbrush density decreased on all treated areas with the largest decrease, 38\%, following roller chopping, shredding, and burning on Area A. Mexican persimmon decreased as much as $68 \%$. Hog plum (Colubrina texensis ( $\mathrm{T}$. \& G.) Gray) density decreased $72 \%$ $(\mathrm{P}<.10)$, while lotebush declined from about 71 to $76 \%$ on all treated areas. Agarito density decreased about $28 \%$ on Areas A and B, but the density was unchanged on the unburned, but roller chopped and shredded Area C. Miscellaneous woody species decreased in density following all three treatments, with the largest decrease on Area A $(\mathbf{P}<$ .10).

Woody stem densities varied considerably among treatments (Fig. 3). Total stem density increased approximately $33 \%$ on Area B and $12 \%$ on Area $\mathrm{C}$ as compared to the

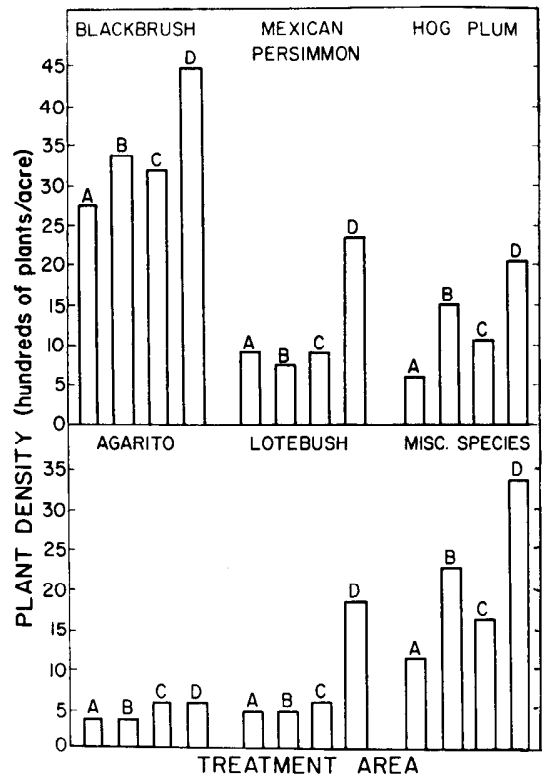

FIs. 4. Woody plant density by major species in 1968 following prescribed treatments. Area A was RC, S, B; Area B was RC, CC, S, B; Area C was RC, S; Area $D$ was untreated.

untreated area. However, a slight reduction was measured on Area A.

The number of blackbrush stems per acre was higher following all treatments (Fig. 5). Increases ranged from about $49 \%$ on Area B to $63 \%$ on the unburned Area C. Mexican persimmon and agarito occurred at lower densities than blackbrush, but similar increases in density occurred. An increase of over 2,650 hog plum stems per acre was measured on Area B. In contrast, hog plum stem densities were reduced on both Areas $\mathrm{A}$ and $\mathrm{C}(\mathrm{P}<.10)$. The grcatest increase in agarito stems followed mechanically clearing without fire. Lotebush stems on Area B increased by approximately 2,800 per acre. However, on the other areas only slight changes occurred in stem densities. Stem densities of miscellaneous species were reduced on all treated areas and were significantly lower on Areas $A$ and $C(P<.10)$ than on the untreated area.

Woody plants averaged about 2.9 stems per plant on the untreated area. With mechanical treatment and burning, the woody plants on Areas $\mathrm{A}$ and $\mathrm{B}$ averaged about 6.6 stems per plant, whilc on the me-

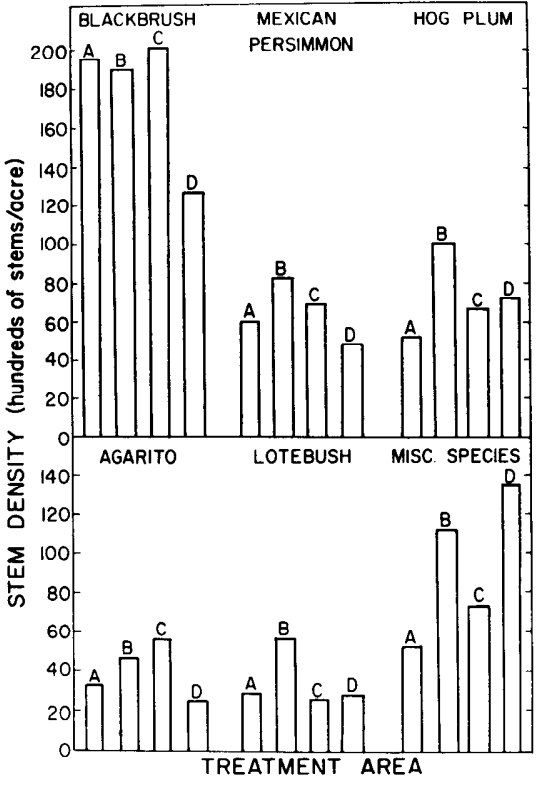

Fig. 5. Woody stem densities, by major species, in 1968, following the prescribed treatments. Area A was RC, S, B; Area B was RC, CC, S, B; Area C was RC, S; Area D was untreated.

chanically cleared, but unburned Area $\mathrm{C}$ the average was 6.1. All treatments and combinations had effectively reduced the stature and canopy of all woody plants.

Changes also occurred in composition of the woody plant cover with treatment (Fig. 6). Blackbrush contributed an average of $11 \%$ more of the composition than before treatment. The greatest increase in percentage composition of blackbrush was on Area $A$ and the least on Area B. Agarito increased in composition on Areas $\mathrm{A}$ and $\mathrm{C}$, but was unchanged on the mechanically cleared, herbicidetreated and burned Area B. Mexican persimmon and lotebush decreased in composition from 1 to $7 \%$ on all areas. Hog plum increased in composition on Area B, but decreased on Area $\mathrm{A}$ and little change was measured on the mechanically cleared, but unburned Area C. Miscellaneous woody species increased in composition on Area B, but decreased following all other treatments.

Basal cover of grasses on the untreated area was significantly lower $(\mathrm{P}<.05)$ than on any of the treated areas (Table 2). Basal cover on the 


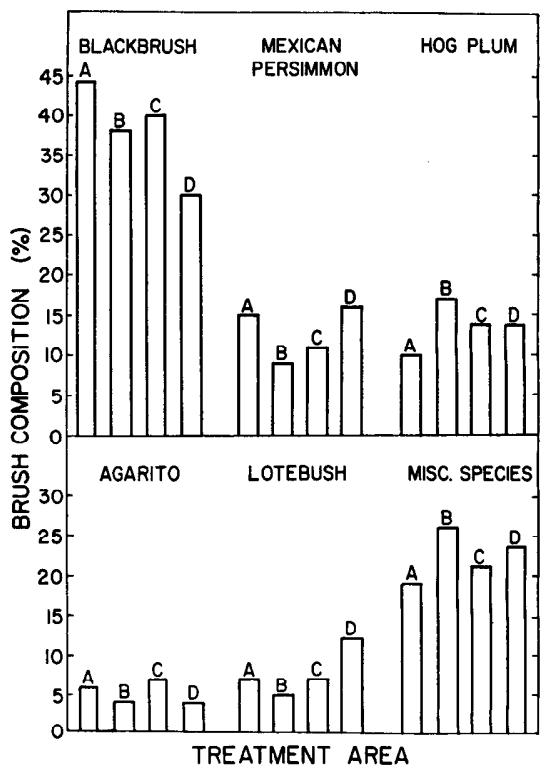

Fig. 6. Woody plant species composition in 1968 following the prescribed treatments. Area A was RC, S, B; Area B was RC, CG, S, B; Area C was RC, S; Area $D$ was untreated.

mechanically cleared, but unburned Area $\mathrm{C}$ averaged $6.6 \%$ while on the mechanically cleared and burned areas (A and $\mathrm{B}$ ) it ranged from 8.0 to $8.2 \%$.

Herbaceous vegetation of mechanically treated and burned areas had a higher percentage of the climax grass species, such as sideoats grama and little bluestem, than the unburned and the untreated areas (Table 2). Areas C and D had more Texas grama (Bouteloua rigidiseta (Steud.) Hitchc.), a weak perennial, than the burned areas. Texas wintergrass (Stipa leucotricha Trin. and Rupr.) contributed more of the herbaceous vegetation on Area $\mathrm{C}$ than on the untreated or other treated areas. Untreated vegetation had the highest percentage of sedges (Carex spp.). Threeawn (Aristida spp.) contributed from 13 to $16 \%$ of the composition of all four areas.

Only data for the most prominent forb species, orange zexmenia (Zexmenia hispida H.B.K.) and Texas broomweed (Xanthocephalum texanum (DC.) Shinners) are reported (Fig. 7). About 660,000 forbs/acre occurred on the untreated area. This was significantly $(\mathbf{P}<.025)$ more than occurred following any treatment. Lowest forb density occurred after mechanical clearing without burning (Area C). Total forb density of areas mechanically treated and burned twice was approximately 460,000 and 510,000 plants/acre, respectively.

Orange zexmenia density on the untreated area was about 51,500

Table 2. Percent basal cover (BC) and percent composition (C) of grass species in 1968 following prescribed treatments. Treatments were for: Area $A$ was RC, S, B; Area B was RC, CC, S, B; Area C was RC, S; and Area D was untreated.

\begin{tabular}{|c|c|c|c|c|c|c|c|c|}
\hline \multirow[b]{3}{*}{ Species } & \multicolumn{8}{|c|}{ Area } \\
\hline & \multicolumn{2}{|c|}{$\mathbf{A}$} & \multicolumn{2}{|c|}{ B } & \multicolumn{2}{|c|}{ C } & \multicolumn{2}{|c|}{$\mathbf{D}$} \\
\hline & BC & C & BC & C & BC & C & $\mathrm{BC}$ & $\mathrm{C}$ \\
\hline Threeawns & 1.3 & 16.4 & 1.1 & 13.3 & 0.8 & 12.7 & 0.9 & 15.5 \\
\hline Sideoats grama & 1.1 & 14.4 & 1.0 & 11.7 & 0.7 & 10.1 & 0.3 & 4.2 \\
\hline Texas grama & 0.9 & 11.4 & 0.9 & 10.8 & 1.3 & 19.7 & 1.2 & 20.0 \\
\hline Sedges & 0.8 & 10.6 & 1.2 & 14.3 & 0.8 & 12.1 & 1.4 & 23.9 \\
\hline Little bluestem & 0.8 & 9.4 & 0.2 & 2.9 & 0.2 & 2.5 & 0.2 & 2.8 \\
\hline Texas wintergrass & 0.5 & 5.9 & 0.5 & 6.3 & 0.7 & 9.8 & 0.3 & 4.2 \\
\hline Southern witchgrass & 0.4 & 4.3 & 0.1 & 0.4 & 0.1 & 1.1 & 0.0 & 0.0 \\
\hline Sandbur & 0.2 & 2.9 & 0.1 & 1.0 & 0.2 & 3.6 & 0.0 & 0.0 \\
\hline Texas tridens & 0.2 & 2.9 & 0.2 & 2.3 & 0.2 & 2.4 & 0.3 & 5.6 \\
\hline Windmill grass & 0.2 & 2.3 & 0.7 & 8.7 & 0.5 & 8.0 & 0.2 & 2.8 \\
\hline Fall witchgrass & 0.2 & 2.1 & 0.2 & 2.6 & 0.1 & 1.3 & 0.1 & 1.4 \\
\hline Southwestern bristlegrass & 0.1 & 1.4 & 0.1 & 1.6 & 0.1 & 1.1 & 0.2 & 2.8 \\
\hline Sand dropseed & 0.1 & 1.4 & 0.4 & 4.9 & 0.1 & 1.4 & 0.1 & 1.4 \\
\hline Miscellaneous species & 1.2 & 14.6 & 1.5 & 19.2 & 0.8 & 14.2 & 0.7 & 15.4 \\
\hline Total Basal Cover & 8.0 & & 8.2 & & 6.6 & & 5.9 & \\
\hline
\end{tabular}

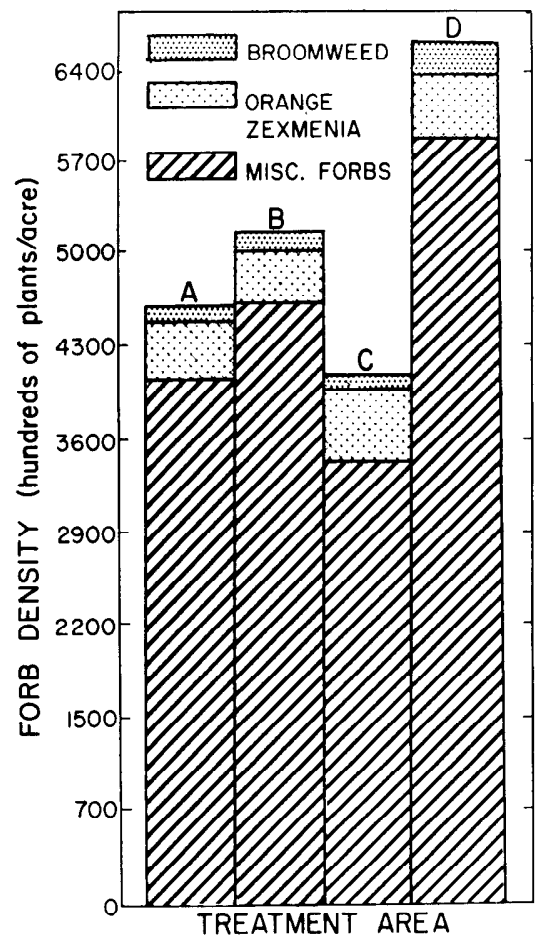

FIG. 7. Plant density of orange zexmenia, Texas broomwecd, and total forbs in 1968 following prescribed treatments. Area A was RC, S, B; Area B was RC, CC, S, B; Area C was RC, S; Area D was untreated.

plants per acre (Fig. 7). However, the highest density occurred on the unburned area $(\mathrm{C})$. Density on the mechanically cleared and burned areas (A and B) was about 46,000 and 42,500 plants/acre, respectively.

Texas broomweed occurred at lower densities than orange zexmenia on all areas (Fig. 7). The highest density, 27,000 plants/acre, was on the untreated area. Density was $61 \%$ lower on Area C, and smaller decreases were measured on the mechanically cleared and burned areas.

Oven-dry grass yield from the untreated area (D) was only 370 lb./acre (Fig. 8). Grass production following mechanical treatment alone was about $890 \mathrm{lb}$./acre or 2.4 times greater than from the untreated area. On the mechanically treated and burned areas (A and $B$ ) grass production averaged from about 1,640 to $1,745 \mathrm{lb}$./acre.

Forb yields were highest on the mechanically cleared, but unburned Area C, exceeding 1,600 lb./acre 


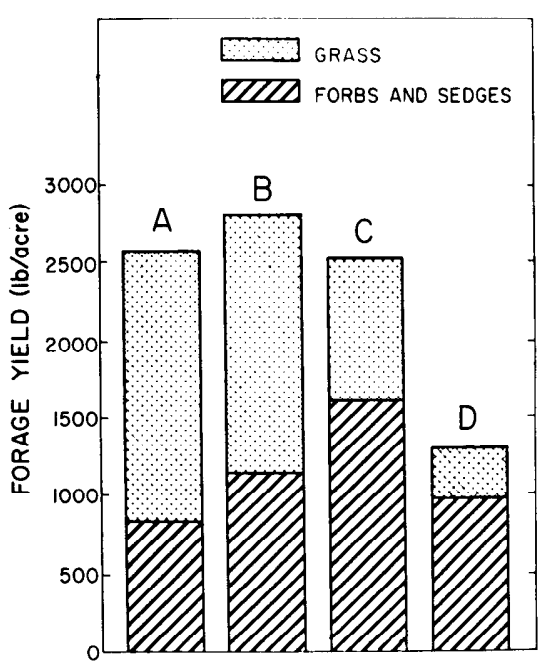

TREATMENT AREA

Fig. 8. Herbaceous forage yields (ovendry) in 1968 following the prescribed treatments. Area $A$ was $\mathrm{RC}, \mathrm{S}, \mathrm{B}$; Area $B$ was RC, CC, S, B; Area $C$ was RC, S; Area D was untreated.

(Fig. 8). The lowest forb yield, approximately $825 \mathrm{lb}$./acre, was from the area (A) mechanically cleared and burned twice. Forb yields on Areas B and D were approximately 1,150 and $930 \mathrm{lb}$./acre, respectively.

Total herbage yield on the four areas ranged from a low of about $1,300 \mathrm{lb}$./acre with no treatment to about 2,800 lb./acre on Area B (Fig. 8). Total production from Areas $\mathrm{A}$ and $\mathrm{C}$ was about $9 \%$ less than Area B.

Litter cover ranged from 20 to $26 \%$ on the mechanically cleared and burncd Arcas A and B (Fig. 9). Considerably more litter occurred on the cleared, but unburned area (C). However, the untreated area had the highest cover, $37 \%$.

\section{Discussion}

Roller chopping and shredding reduced overall stature, canopy cover, and plant density (47\%) of woody species. In general, these treatments increased stem densities due to basal sprouting. These responses are similar to those reported by Box et al. (1967) and Dodd (1968).

Two consecutive years of late summer burning following roller chopping and shredding decreased woody plant density, but increased

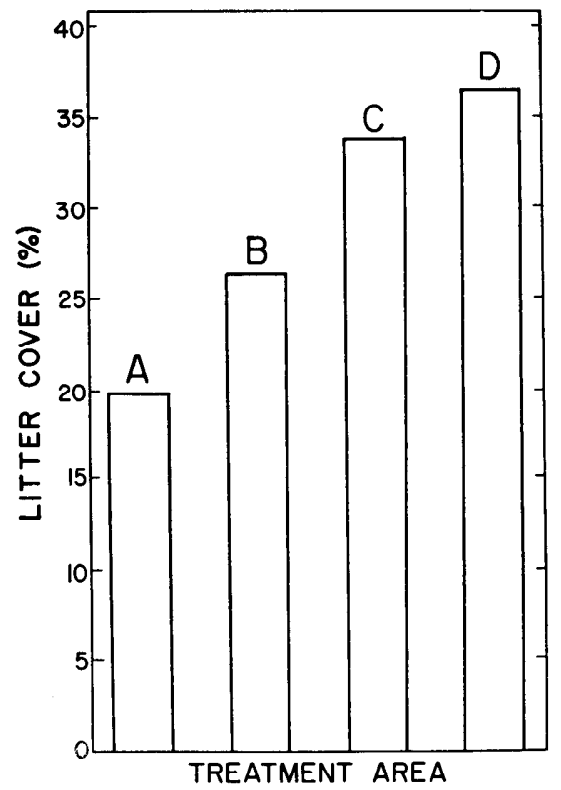

Fig. 9. Litter cover in August 1968, following the prescribed treatments. Area A was RC, S, B; Area B was RC, CC, S, B; Area C was RC, S; Area D was untreated.

the number of stems per woody plant. Similarly, Britton and Wright (1971) reported that burning topkilled most woody plants, but vigorous resprouting occurred from underground buds.

Blackbrush, the most prominent species, increased in composition, regardless of treatment. In contrast, lotebush and Mexican persimmon decreased in composition after all treatments. Hog plum and miscellaneous species, such as live oak, pricklyash (Zanthoxylum fagara (L.) Sarg.), and kidneywood increased in composition with mechanical-herbicide stump treatment.

Range condition, based on percentage original vegetation present (Dyksterhuis, 1949), was highest after mechanically clearing and burning. Greater improvement in range condition on these areas was probably the result of clearing two years earlier than the area (G) mechanically cleared without burning. The mechanically treated and burned areas supported one-third more herbaceous basal cover than the untreated area, total herbage production was doubled, and grass production was almost 5 times greater. Grass foliage contributed over half of the total herbage produced on the mechanically treated and burned areas contrasted to only $28 \%$ of the production with no treatment. Total herbage production on the area mechanically cleared alone was similar to that of the mechanically cleared and burned areas. However, a large percentage of the production was contributed by forbs and sedges, a condition similar to that of the untreated area. With lime and treatment a shift from forb and sedge to perennial grass production occurred.

Total forb density was significantly reduced but production was generally increased by all treatments. This inverse relationship between forb density and plant size probably reflects the influence of a woody plant canopy on herbaceous plant growth.

Two consecutive years of late summer burning decreased litter cover. Similar reductions have been reported in other areas (McMurphy and Anderson, 1965; Ahlgren and Ahlgren, 1960).

\section{Literature Cited}

Ahlgren, I. F., ANd C. E. Ahlgren. 1960. Ecological effects of forest fires. Bot. Rev. 26:483-533.

Aldous, A. E. 1934. Effects of burning on Kansas bluestem pastures. Kans. Agr. Exp. Sta. Tech. Bull. 38. $65 \mathrm{p}$.

ANderson, K. 1964. Burning Flint Hill bluestem ranges. Procccdings: Tall Timber Fire Ecol. Conf. 3:89105.

Bovey, R. W., J. R. Baur, and H. L. Morton. 1970. Control of huisache and associated woody species in South Texas. J. Range Manage. 23: $47-50$.

Box, T. W., J. Powell, and D. L. Drawe. 1967. Influence of fire on South Texas chaparral communities. Ecology 48:955-961.

Britton, C. M., and H. A. Wright. 197J. Correlation of weather and fuel variables to mesquite damage by fire. J. Range Manage. 24:136141.

Campbell, J. A., and J. B. Cassody. 1951. Forage response to month of burning. U. S. Forest Serv. Res. Note SE-35. 4 p. 
Clark, S. E., J. A. Campbell, and J. B. Camprell. 1942. An ecological and grazing capacity study of the native grass pastures in southern Alberta, Saskatchewan, and Manitoba. Dom. Can. Dep. Agr. Tech. Bull. 44. $31 \mathrm{p}$.

Dod,, J. D. 1968. Mechanical control of pricklypear and other woody species on the Rio Grande Plains. J. Range Manage. 21:366-370.

Dyksterhuis, E. J. 1949. Condition and management of range land based on quantitative ecology. J. Soil and Water Conserv. 16:186-187.

Gould, F. W. 1969. Texas plants. Tex. Agr. Exp. Sta. MP-585. 121 p.

Hensel, R. L. 1923. Effect of burning on vegetation in Kansas pastures. J. Agr. Res. 23:641-647.

Humphrey, R. R. 1953. The desert grassland, past and present. J. Range Manage. 2:173-182.

Humphrey, R. R. 1958. The desert grassland a history of vegetational change and an analysis of causes. Bot. Rev. 24:193-252.

LEINWEBER, C. L. 1965. Managing a million acres of grass. Texas Agr. 11:18-21.

Levy, E. B., And E. A. Madden. 1933. The point method of pasture analysis. New Zealand J. of Agr. 46:267279.

McKell, C. M., A. M. Wilson, And B. L. KAY. 1962. Effective burning of rangelands infested with medusahead. Weeds 10:125-131.

MaMurphy, W. E., ANd K. L. AndersoN. 1965. Burning Flint Hills range. J. Range Manage. 8:163-169. Oosting, H. J. 1942. An ecological analysis of the plant communities of Piedmont, North Carolina. Am. Midl. Nat. 28:1-126.

Owensby, C. E., and K. L. Anderson. 1967. Yield responses to time of burning in the Kansas Flint Hills. J. Range Manage. 20:12-16.

U. S. Dep. Agr. 1964. Grassland restoration: The Texas brush problem. Unnumbered Bull. U. S. Dep. Agr., Soil Cons. Serv., Temple, Texas. $17 \mathrm{p}$.

U. S. Dep. Agr. 1965. Range technician's guide, Goliad work unit. U. S. Dep. Agr., Soil Cons. Serv. (mimeo.). 4 p.

Whitman, W. G., and E. I. Siggeirsson. 1954. Comparison of line interception and point contact methods in the analysis of mixed grass range vegetation. Ecology 35:431-436. 